\title{
WESTERN PATTERNS IN FORESTRY EDUCATION IN THE RUSSIAN EMPIRE IN THE MID-18TH - MID-19TH CENTURIES
}

\author{
Elena Lustina \\ Faculty of History, Communications and Tourism \\ of Yanka Kupala State University of Grodno \\ Oktyabrskaya str. 5, Grodno, 230023 Republic of Belarus \\ Telephone/fax: +375152730391 \\ E-mail: elena.lu@mail.ru
}

Received on 24 February, 2014; accepted on 24 March, 2014

doi:10.13165/SMS-14-6-1-05

\begin{abstract}
The present paper refers to the formation and development of forestry education and science in the Russian Empire during the mid-18th - mid-19th centuries. Given the progressive interest in environmental protection, forest resources and the historical study of this problem, it is necessary to emphasize the importance of analyzing the whole range of issues related to the problem. The relevance of the topic is not only connected with its topicality, but also with its scarce study and the fact that it has an educational character. The article renders the influence of Western European countries on this process and a characteristic of forestry education in some Western European countries. The author analyzed various sources and literature on the topic of research and attempted to restore the stages of origin, formation and development of forestry education and science in the Russian Empire in the mid-18th - mid-19th centuries, as well as the changes in introducing and applying the Western European patterns into practice.
\end{abstract}

Keywords: history, forestry education, Russian Empire, forestry, forest conservation.

Socialinių mokslų studijos / Societal Studies

(C) Mykolo Romerio universitetas, 2014

(C) Mykolas Romeris University, 2014
ISSN 2029-2236 (print), ISSN 2029-2244 (online) http://www.mruni.eu/lt/mokslo_darbai/SMS/ http://www.mruni.eu/en/mokslo_darbai/SMS/ 


\section{Introduction}

The current environmental situation makes it necessary to study the whole range of issues of forest exploitation and exploration as well as forestry education in the Russian Empire and in the countries of Western Europe. Relevance of the topic is conditioned not only by its actuality, but by its insufficient coverage and exploration, as well as its educational nature. The aim of the present research is to restore the development of forestry education in the Russian Empire, evolution and dissemination of forestry knowledge at different stages. The object of the research is social and cultural life of the society of the Russian Empire and some Western European countries. Influence of the Western European tradition on the formation of forestry education in the Russian Empire in the mid-18th - mid-19th centuries is discussed, as well. The following methods were used when working on this study: comparative historical method, historical and typological methods and method of historical analysis.

In the history of all civilized countries, there is a tendency towards move from the abundance of forests to their deficiency. Most European countries possessed vast forest areas, but with the development of society, economy and manufacture with the use of forest resources, condition of forests in European countries shifted towards impoverishment. The Russian Empire, previously rich with forest areas, made no exception. Its forests attracted timber merchants, shipbuilders, the so-called wood stealers, who devastated forests. The need appeared for a scientific approach, forestry science theory and for its practical application, the need for model forestry and special knowledge dissemination. European countries managed to stop the process of devastation, largely due to the knowledge on forest reservation and reforestation. Germany especially succeeded in reforestation. Great attention was paid here to education of forest specialists; numerous educational institutions were organized for this purpose. They became popular not only with European students, but also with students of Slavic origin, immigrants from the Russian Empire.

This article presents the history of transformation of forestry education in the Russian Empire, beginning with imitation of Western European patterns, especially the German ones, to the establishment and development of national forestry science.

\section{Integration of forest specialists}

Guided by the experience of more progressive forest farms of Western countries, the Russian Empire widely used the practice of invited foresters.

Being the most developed, German forestry was followed the most. Therefore, German forest experts were often invited to the Russian Empire to do some forestry work and share their experience with local students. 
In 1726, three German specialists first came to Russia, who later were called forest experts from Hamburg. They were Ferdinand Gabriel Vökel, who was the most experienced one, Melchior Zelger and Yagan Valentin Mertsgunmer.

All three were "to examine and describe forests suitable for shipbuilding; to maintain, protect and clean them, detect time of logging, floating ways, etc." Each expert was supplied with a German servant and an interpreter. To facilitate the work, they were given workers. They were supposed to have 6 students to share the experience with ${ }^{1}$.

They concluded contracts for 4 years.

Yagan Valentin Mertsgunmer finished the job and six years later returned to Germany. Melchior Zelger planted a lot of new forests. He died in Russia.

Ferdinand Gabriel Vökel devoted himself to the forests of the Russian Empire, was appointed as a superintendent at the Admiralty Board. His duties ranged widely.

As a result, Vökel in his 25 years of service in Russia discovered and described numerous forests of North and West in inventory books. He identified the areas suitable for the cultivation of ship forests and personally was engaged in this work, including laying-in of seeds, sowing, caring for young growth, etc. In March of 1732, Vökel made a project called "How sow and take care of oak woods". He is the author of the provision that was converted into statute by a special decree "On forest sowing and planting for the fleet of Her imperial majesty"2.

These famous German foresters did much to multiply and improve forests of the Russian Empire; they taught a lot of Russian students.

Nevertheless, the invited experts did not solve the problem of lack of qualified local personnel, despite the possibility of getting forestry education in Europe.

\section{Forestry education in Europe}

Western Europe was considered to be the cradle of forestry education. The first mentions of forestry school date back to 1500, when the school in Venice was opened. The next one was opened by a certain Tsantir in Germany, Harz in Ilsenburg in 1772. Forestry science was spreading in Germany and a number of profile schools was increasing in different parts of the country, both private and state ${ }^{3}$.

40 forest schools had been opened in Germany by $1832^{4}$.

1 Lesnova, A. Kak tri nemtsa rossiiskie lesa obshchitali, raschistili i preumnozhili [How Three Germans Counted, Cleared and Augmented Russian Forests]. Lesprominform. 2006, 5: 34-35.

2 Lesnova, A., supra note 1, p. 34-35.

3 Zhudra, P. Zagranichnye vpechatleniya russkogo lesnichego [Overseas Impressions of Russian Forester]. Lesnoi zhurnal. 1885, 9(2): 433.

4 Obschestvo dlia pooschrenija lesnogo choziajstva [Association for Forestry Encouragement]. Lesnoi zhurnal, izdavaemyi obshchestvom dlya pooshchreniya lesnogo khozyaistva. 1833 ch. $1 \mathrm{kn} .1$ [Forest Journal published by the Society of Encouragement of Agriculture]. SanktPeterburg: Tipografiya Departamenta Vneshnei torgovli, 1833, p. 236. 
Russian forestry students obtained higher education in Tarand Forest Academy, which was founded in Saxony in 1821.

Slavic students of Tarand Academy organized a society without external differences and statutes. The society was mainly for communication and intellectual development, for organization of mutual financial aid. Slavic society was approved by professors. Meetings were held once a week. They consisted of discussions of various issues, reading of essays and reports, lively debate ${ }^{5}$.

Tarand Forest Academy possessed good practical facilities. A total area of academic wood land exceeded 1000 hectares and had a very convenient location ${ }^{6}$.

It should be noted that in Saxony all closely located forests of the kingdom were allowed to be used by professors and students. Students received both theoretical and practical knowledge, which was a distinctive feature of German education. The activity of Forest Academy was closely connected with practical life.

Zhudra during his trip to Saxony noted that forestry itself and Russians involved in forestry were respected not only by scientist and forest officials, but by ordinary people, as well ${ }^{7}$.

One of the most famous European universities with forestry programme was Munich University in Germany. Its most prominent professors were the following ones: doctor Ebermayer, famous for his research on how forests affect climate; botany professor Robert Gartsig, who created the science of entophytes and plant diseases; Karl Gayer and others ${ }^{8}$.

In 60 s of the 18 th century, European forest educational institutions were divided into 2 types: only theoretical and only practical.

Departments of Forestry were established in most universities (except Prussian) of the first type.

Many governments admitted that only theoretical knowledge was insufficient, and therefore, they initiated organization of purely practical forest schools. Wernigerode school in Harz (Germany) founded in 1767 was the most famous one 9

Among other European institutions specialized in forestry, the following ones should be mentioned: Danish forestry school in Kiel, which was founded in 1785, High Forest School in Berlin founded in 1821 (later it was transferred to Eberswalde), the First State Forest Institute in Nancy (France) founded in 1825, Forest institution in Austria (not far from Vienna) founded in 1814, Forest Institute in England founded in 1886 , etc. ${ }^{10}$

$6 \quad$ Ibid., p. 433.

7 Ibid.

$8 \quad$ Ibid., p. 469.

9 Obschestvo dlia pooschrenija lesnogo choziajstva [Association for Forestry Encouragement], supra note 4, p. 102.

$10 \quad$ Ibid., p. 108. 
In the present paper, a closer look at the Forest Institute in Nancy will be taken. The Forest Institute in Nancy was founded in 1825 to educate forest officials. Moreover, secondary schools were organized in most forest-rich areas to raise forest guards. All aspects of forest sciences, natural sciences, drawing, German (to study profile literature, as it was mainly in this language) were taught at the University. Study course lasted 2 years. Students were divided into 2 classes according to their abilities; a three-year course was intended for poorly performing students. The number of students was limited to 24 , according to the need for forest officials. Education was free of charge ${ }^{11}$.

\section{Origin and development of forestry education in the Russian Empire}

By the end of the 18th century, almost nothing had been done in respect of education and training of forest officials in the Russian Empire. Empress Anna Ioanovna ordered to appoint students to each superintendent, who would teach them and hand over their positions later. Also, she ordered to allocate a certain number of assistants to each superintendent, so the former could gain some knowledge and skills in forestry, as well. But this step did not become successful, because the teachers were foreigners and not familiar with Russian customs, the Russian language, the administrative side of the issue, and sowing and planting were not extensive, so that assistants and students were occupied mainly at offices with reporting documentation and some red tape.

In 1799, four alumni of the Marine Corps were sent to England to study forest cultivation in the royal groves supplying fleet. In 1800, a superintendent class was organized at the Marine Corps for teaching forest sciences to some cadets ${ }^{12}$.

The situation remained unchanged also because until the end of the 18th century no special knowledge was required from applicants for positions of forest workers. But in 1798, a new rule was introduced for applicants for positions of head foresters or superintendents. They had to pass tests in forestry at a special committee of the Admiralty Board, as the need for specialists with sufficient knowledge in theoretical and practical forestry appeared for forest farming of state forests.

Gradually following western patterns and attracting western experts in forest management practice was becoming obsolete.

11 Obschestvo dlia pooschrenija lesnogo choziajstva.[Association for Forestry Encouragement]. Lesnoi zhurnal, izdavaemyi obshchestvom dlya pooshchreniya lesnogo khozyaistva. $1833 \mathrm{ch} .1$ kn. 2 [Forest Journal published by the Society of Encouragement of Agriculture]. Sankt-Peterburg: Tipografiya Departamenta Vneshnei torgovli, 1833, p. 250.

12 Arnol'd, F.K. Istoriya lesovodstva v Rossii, Frantsii I Germanii [History of Forestry in Russia, France, Germany]. Sankt-Peterburg: A.F. Marksa, 1895, p. 219. 
Governments of Alexander I faced many problems: forestry was not profitable enough for the treasury; there was no well-organized management of forests; and still there was a shortage of Russian workers in administration. Germans were occupied in administration.

The department sent an official statement to the Minister of Finance Vasilyev A.N.: "The more forestry in Russia develops, the greater the shortage of local qualified foresters is. Foreigners are not able to fully apply all their practical and theoretical knowledge as they do not know language, traditions and laws of the country, and they do not know the unique properties of the soil and the product given by nature"13.

Meanwhile, according to Vasilyev, Minister of Finance, officials appointed to positions of forest superintendents (foresters) and head foresters did not have the required knowledge, "because there are no people in Russia who are competent in forestry". Therefore, in 1802, the Charter of the Forest was supplemented with the clause stipulating "to establish schools for education and training in forest sciences". In a year after the adoption of this clause of the Charter of the Forest, its requirement was first put into effect. The Charter of the Forest of 1802 initiated the organization of forest schools ${ }^{14}$.

On May 19, 1803, the Provision on the establishment of Practical Forestry School in Tsarskoye Selo was approved.

In 1803-1804, forest schools were established in the Marine Corps instead of the common class: in Tsarskoye Selo for 20 students (and it was renamed into Tsarskoselsky Forest Institute); in Kaluga province, Kozelsk for 30 students, etc. In 1808, Count Orlov opened Forest Institute on Yelagin Island.

From 1811 to 1813 , these institutions were merged into St. Petersburg practical Forest Institute. A park, a library, botany, physics and chemistry study rooms were opened at the Institute. The number of students counted up to 108 people.

Over a six-year study course, a variety of disciplines was conducted: arithmetic, algebra, geometry, trigonometry, geodesy, forestry, natural history, forest botany, physics, chemistry, forest statistics, forest laws, the law of God, history, geography, accounting, drawing, Russian and German, shooting, yager's art, as well as music and dancing. Institute's own groves and plantations were used for student practical trainings. Practical exercises on profile forest disciplines were mainly conducted in Lisinsky wood land. But Lisinsky wood land was quite limited by the nature of plantation, its physical and economic conditions ${ }^{15}$.

13 Privalygin, V. Lesnoi Departament Rossii. Pervye shagi.[ Forest Department in Russia. The First Steps] [interactive]. 2013 [accessed on 2013-12-10]. <http://www.krasrab.com/archive/2013/10/12/18/view_article $>$.

14 Nekhoroshev, T.V. Kratkij obzor deyatel'nosti Kazennogo lesnogo upravleniya za 1893-1902 gg. [Short Review of Activities of State Forest Administration in 1893-1902]. Sankt-Peterburg: 1903, p. 255.

Ibid., p. 261. 
Warsaw School of Forestry. Warsaw School of Forestry was founded in 1816. A that time, Warsaw was the capital of the Kingdom of Poland, which was a part of the Russian Empire. Students coming to study at Warsaw School of Forestry had to provide evidence of basic knowledge in forestry; on the basis of their expertise they were defined in one of three classes. Practical activity in the school was divided into three areas: forest management, geometric and book-keeping on forest issues.

Theoretical part of the course included the following disciplines: mathematics, natural sciences, zoology, botany, mineralogy, German, all aspects of forest sciences and yager's art. The Institute library was updated annually. There was a study room with forestry exhibits, models of forest and yager's guns. Direct practical trainings were held in Bozdentyshsky forest district, where students had a special housing. At the end of practice, students had the exam.

School Board, which was chaired by Chief Director of state-owned forests, published forest magazine "Dziennik nauk lesnych i loveckich".

In 1840, Warsaw School of Forestry was joined with Novo-Alexandria Institute of Agriculture and Forestry which was founded in 1816 in Warsaw suburbs. In 1860, it was transferred to Novo-Aleksandria, Lublin province, which later became the first Institute of Agriculture and Forestry in Russia.

The Institute possessed a museum of agriculture, which was one of the best in Europe, 3 laboratories, 20 study rooms, a veterinary clinic, a meteorological station, experimental farms, greenhouses, forest nurseries, a library and a reading room (with about 200 publications $)^{16}$.

Lack of qualified specialists in forestry remained a relevant problem.

By 1838, only 84 forest officials out of 507 had special education in forestry ${ }^{17}$.

The state became interested in training educated forest officers of lower ranks. Military nature of the service was supposed to promote self-discipline and high moral qualities. In this regard, Minister of State Property Kiselev P.D. initiated transformation of the Forestry Institute into a military school.

In 1837, St. Petersburg Forest Institute was reorganized into Institute of Forestry and Surveying, which was divided into two companies: forest and surveying. The number of students increased. The course was expanded ${ }^{18}$.

In 1862, Institute of Forestry and Surveying was closed. Forest Academy was founded, and it functioned up to 1865. In place of St. Petersburg Forest Academy, Petrovsky Agricultural and Forestry Academy was opened near Moscow in the same year. In Petrovsky Academy, forest specialty was independent (1859-1864). Aleksandriiskogo instituta sel'skogo khozyaistva i lesovodstva za 1907 god. [Report on Activities of Novo-Alexandria Agriculture Institute]. Sankt-Peterburg: Tip. M.A. Aleksandrova, 1909, p. 9. 
Forestry teaching continued in St. Petersburg Agricultural Institute located in the premises of the former Forest Institute, where this in 1863 new institution was transferred from Mogilev province, where it was called Gory-Goretsky Agricultural Institute $^{19}$.

In 1848, Gory-Goretsky Agricultural Institute was reorganized from GoryGoretsky Agricultural School, where forest specialists had been trained, as well.

In Gory-Goretsky Agricultural Institute, forestry was not a separate, independent specialty, but a supplementary one to agricultural specialty. As a result, those who graduated from the Institute and attended an additional course in forest sciences and forest technology could get the title of the student of agronomy and forestry.

Thus, forest officials could be educated in two institutions of higher education, not taking into account Novo-Alexandria Forestry Institute of Warsaw educational district of the Russian Empire.

Later on, higher forestry education in the Russian Empire was improving along with the demand for forest specialists in forest administration.

As for primary forest schools, up to 1838, there was only one school of such type in the Russian Empire - Lisinsky Yager School.

Gradually, yager schools began to open in other provinces: in 1844, Yager and Clerk School was opened in Ostrovsky estate of Moscow province; in 1847, Yager school was established in a government estate Sokolka of Grodno province; in 1850, Forest Manufacturing School was opened at Volgograd model farm; in 1858, Lipetsk Yager school started to function at Romanov's state wood land in Lipetsk district of Tambov province ${ }^{20}$; in 1863, Yager and Clerk School was opened in Grodno province $^{21}$.

At the beginning, requirements at primary schools were not high: education there was to be mainly practice-oriented, graduates were supposed to provide necessary assistance to foresters. In some time, however, the Ministry put greater demands on primary schools. They became institutions for training guards, forester assistants who could administer a forest district independently. This step of the Ministry caused the lack of graduates from institutions providing higher education.

The Ministry saw the solution in reduction the number of institutions and their integration into one progressive school, where the best staff would be occupied. Thus, all schools were closed gradually, excluding Lisinsky Yager School, which was renamed into Lisinsky Forest school in $1869^{22}$.

Taking care of the quality of education in forest schools, the government relied on qualified teaching staff, which consisted mainly of immigrants from Western

19 Arnol'd, F.K., supra note 12, p. 271.

20 Ibid., p. 272.

21 «O uchrezhdenii pisarsko-eger'skogo uchilishcha v Grodnenskoi gubernii v 1863g» Litovskii istoricheskii arkhiv v Vil'nyuse [On Establishment of Yager and Clerk School in Grodno Province. Lithuanian Historical Archive in Vilnius]. F. 378. Op. 1863. D. 859. L. 2. 
countries. Working trips abroad were organized for exchange of experience and professional growth, and not only teaching staff was forwarded for trainings, but forest officials, as well.

"Nothing has such educational value as direct acquaintance with the way how the work is done elsewhere; such travels wake up mind, refresh feelings, teach to think geographically and give plenty of material for comparative study", noted Morozov G.F., Professor of Forest Institute, who had a two-year working trip to Germany ${ }^{23}$.

Thus, economic situation, state of forestry forced the government to pay attention to "the development of science as the only true foundation for consistent forestry" 24 .

\section{Education}

Forestry being on a high level in some European countries started to develop in the Russian Empire only in the 18th century.

As there was few forestry material in Russian literature, original sources, mostly German, and translations from English and Swedish were used.

By the middle of the 18th century, there were up to 20 units of literature in Russian $^{25}$.

The first work in forestry in the Russian language was published in 1766: "Description of the natural state of forests growing in the northern Russian countries, with different notes and instructions on how these should be cultivated". The author of the work was forest superintendent F. Vökel. The original work was written in German, then translated into Russian and published by the order of the Admiralty Board. For that time, it was a very deep work containing a lot of interesting observations and useful instructions.

Before Vökel's book edition, there had been known some manuscript writings, which were printed later in the 19th century, e.g., "Ordination of royal forests in forest areas of the former Grand Duchy of Lithuania, compiled according to the instructions of King Wladyslaw IV by commissioners Peter Dalmatov Isaykovsky in 1641" (published in 1871) ${ }^{26}$; "Revision of forests and animal passages in the former Grand Duchy of Lithuania with granting charters and privileges to admission to

23 Beilin, I.G.; Parnes, V.A. G.F Morozov. Moscow: Nauka, 1971, p. 35.

24 Shelgunov, N.V. Istoriya russkogo lesnogo zakonadatel'stva [History of Russian Forest Legislation]. Sankt-Peterburg: Ministerstvo Gosudarstvennyh Imushchestv, 1857, p. 331.

25 Obschestvo dlia pooschrenija lesnogo choziajstva [Association for Forestry Encouragement], supra note 4, p. 219.

26 Ordinatsiya korolevskikh pushch $v$ lesnichestvakh byvshego Velikogo knyazhestva Litovskogo, sostavlennaya po instruktsii korolya Vladislava IV komissarami, Petrom Dalmatovym Isaikovskim $v 1641$ godu [Ordination of royal dense forests in forestries of the former Grand Duchy of Lithuania, compiled according to the King Vladislav IV instructions, by commissar Petr Dalmatov Isakovsky in 1641]. Vil'no: Tipografiya shtaba Vilenskogo voennogo okruga, 1871. 
forest and grounds, compiled in 1559 by Gregory Bogdanovich Volovich, Mstibogov starosta" (published in 1867) ${ }^{27}$.

Till 1838, forestry literature in the Russian Empire was poor. Translations from German and English were published as previously: in 1803, translation of Burgsdorfs writings was published (edited by Bakunin); in 1813, translation of Hartig's "Lehrbuch für Förester" was compiled by Pogankov and Kireevsky. In 1805, Yuzefov translated "On cultivating timber and other useful forests" from English.

Later, several original Russian writings were published, but they did not become very popular.

Work of forester and scientist Peter Perelygin "Inscription of forestry rules" and "Forest protection or principles of preservation of growing forests" should be noted, published in two parts in 1831 and 1835, respectively.

The most significant writing of this period is considered to be "Instructions on forest administration on the mountain factories of the Ural mountain range, according to the rules of forest science and good management", published by the Minister of Finance in 1830. The Instructions appeared to be a quality well-organized academic work ${ }^{28}$.

Poverty of Russian literature in forestry could be partially explained by the fact that western forestry literature was very progressive, and therefore, mainly translations were published. Most of translated authors were Germans: Hudeshagen, Wedekind, Kotta ${ }^{29}$. Writings of foreign authors were not commonly popular, because they were translated literally without necessary additions concerning the state of forests in the Russian Empire. Among readers of this literature, there appeared some discontent and belief that "foreign forestry rules cannot be applied to Russian forests. Fundamentals of forestry, as well as vegetation laws are the same both in Russia and in Germany, but local circumstances require deviation from general rules" 30 .

During the reporting period, Germany officially recognized an important influence of the territory characteristics on forestry; almost every single state had its own special rules of reforestation. So, taking into consideration vast territories of the Russian Empire, there could not be a single pattern applied in all cases of forest farming and reforestation. It is impossible to accept a common forest system that would be Velikom Knyazhestve Litovskom [Revision of dense forests and animal paths in the former Grand Duchy of Lithuania]. Vil'na: V tipografii Gubernskogo Pravleniya, 1867.

28 Arnol'd, F.K., supra note 12, p. 252.

29 Kottę( Cotta), H. O uprawie lasow. Przez Henryka Kottę (Cotta),Krolewsko-Saskiego Radzcę nadleśnego, Dyrektora Akademii leśnictwa i pomiaru lasow, Kawalera Krolewsko-Saskiego orderu zastugi czwilnej i czlonka wielu uczonych towarzystw. Piąte poprawne wydanie. Poznań: Nakladem Teodora Scerka, 1838. - c.v.

30 Henke, K. Nauka urzadyzania, szacowania i oceniania lasow. urzednika do szcegolnych poruczeń w kommissyi rząndowejprzychodow i skarbu, professora leśnictwa w kommissyi examinacyjnej gubernii Warzawskiej. Warzawa: W drukarni S. Orgelbranda, 1846. - VII. 
suitable for all areas of European Russia. But numerous and accurate researches and observations were needed to specify a forestry pattern for each province. Lack of such studies explains the poverty of literature in forestry in the period of the study. This may also be an explanation for forced stagnation in forestry literature, until required research material accumulated. Summaries and recommendations were not possible.

Founding of "Forest Journal" in 1832 became very important for education in forestry. First, it was published by the society for promotion of forestry, then from 1850 - by the Imperial Free Economic Society ${ }^{31}$.

Thus, society for promotion of forestry took responsibility to report and to disseminate useful information regarding proper forest management, to familiarize with the writings on forestry.

"Forest Journal" was ceased in 1850, and until 1855 forestry had no particular profile periodical ${ }^{32}$.

\section{Conclusion}

The need for implementing of scientific measures, for theoretical forestry and its practical application, for introduction of model forestry and dissemination of specific knowledge revealed inconsistency of Russian forestry, forest science and lack of qualified specialists in this area. The solution of many problems was sought in the experience of Western countries, borrowing their practice, learning from their experience, involving invited experts to foundation and development of national forest education and forest science in the Russian Empire. Eventually, shortcomings of blind imitation and replication of the achievements of Western European patterns in the Russian Empire became obvious, which resulted in a progressive tendency towards rejection from full imitation of practical application of scientific knowledge because of specific soil, climatic, cultural, administrative and management features on vast territories of the Russian Empire.

\section{References}

Arnold, F. K. Istoriya lesovodstva v Rossii, Frantsii I Germanii [History of Forestry in Russia, France, Germany]. SanktPeterburg: A. F. Marksa, 1895.

Beilin I.G.; Parnes V.A. G.F Morozov.

Moscow: Nauka, 1971.
Bode, A. Karmannaya kniga dlya russkogo lesnichego na 1855 god [Pocket Book for Russian Forester for 1855]. SanktPeterburg: Tipografiya Imperatorskoi Akademii nauk, 1854.

31 Bode, A. Karmannaya kniga dlya russkogo lesnichego na 1855 god [Pocket Book for Russian Forester for 1855]. Sankt-Peterburg: Tipografiya Imperatorskoi Akademii nauk, 1854, p. 128. Arnold, F. K., supra note 12, p. 363. 
Henke, K. Nauka urządyzania, szacowania $i$ oceniania lasow., urzednika do szcegolnych poruczeń $w$ kommissyi rząndowejprzychodow i skarbu, professora leśnictwa $w$ kommissyi examinacyjnej gubernii Warzawskiej, kawalera orderow ś. Anny i ś. Szanisława klassy 3. Warzawa: W drukarni S. Orgelbranda, 1846.

Institut lesnogo choziajstva. [Institute of Agriculture]. Otchet o sostoyanii $i$ deyatelnosti Novo-Aleksandriiskogo instituta selskogo chozyaistva $i$ lesovodstva za 1907 god [Report on Activities of Novo-Alexandria Agriculture Institute]. Sankt-Peterburg: Tip. M.A. Aleksandrova, 1909.

Kottę (Cotta), H. O uprawie lasow. Przez Henryka Kottę (Cotta), KrolewskoSaskiego Radzcę nadleśnego, Dyrektora Akademii leśnictwa i pomiaru lasow,Kawalera Krolewsko-Saskiego orderu zasługi czwilnej i czlonka wielu uczonych towarzystw. Piąte poprawne wydanie. Ułożone przez Augusta Kottę (Cotta), Krolewsko-Saskiego Inspektora lasow i nauczyciela Akademii leśnictwa. Z dwiema tablicami. Poznań: Nakladem Teodora Scerka, 1838.

Lesnova, A. Kak tri nemtsa rossiiskie lesa obshchitali, raschistili i preumnozhili [How Three Germans Counted, Cleared and Augmented Russian Forests]. Lesprominform. 2006, 5: 34-35.

Nekhoroshev, T.V. Kratkii obzor deyatel'nosti Kazennogo lesnogo upravleniyaza 1893-1902 gg [Short Review of Activities of State Forest Administration in 1893-1902]. Sankt-Peterburg: 1903.

Obschestvo dlia pooschrenija lesnogo choziajstva [Association for Forestry Encouragement]. Lesnoi zhurnal, izdavaemyi obshchestvom dlya pooshchreniya lesnogo khozyaistva. 1833 ch. 1 kn. 1 [Forest Journal published by the Society of Encouragement of Agriculture]. SanktPeterburg: Tipografiya Departamenta Vneshnei torgovli, 1833.

Obschestvo dlia pooschrenija lesnogo choziajstva. [Association for Forestry Encouragement]. Lesnoi zhurnal, izdavaemyi obshchestvom dlya pooshchreniya lesnogo khozyaistva. $1833 \mathrm{ch} .1 \mathrm{kn} .2$ [Forest Journal published by the Society of Encouragement of Agriculture]. Sankt-Peterburg: Tipografiya Departamenta Vneshnei torgovli, 1833.

Ordinatsiya korolevskikh pushch v lesnichestvakh byvshego Velikogo knyazhestva Litovskogo, sostavlennaya po instruktsii korolya Vladislava IV komissarami, Petrom Dalmatovym Isaikovskim $v 1641$ godu [Ordination of royal dense forests in forestries of the former Grand Duchy of Lithuania, compiled according to the King Vladislav IV instructions, by commissar Petr Dalmatov Isakovsky in 1641]. Vil'no: Tipografiya shtaba Vilenskogo voennogo okruga [Printing house of headquarters of Vilnius military district], 1871.

«O uchrezhdenii pisarsko-egerskogo uchilishcha v Grodnenskoi gubernii v 1863g» [On establishment of Yager and Clerk School in Grodno province in 1863]. Litovskii istoricheskii arkhiv v Vil'nyuse [Lithuanian Historical Archive in Vilnius]. F. 378. Op. 1863. D. 859. L. 2. Privalygin, V. Lesnoi Departament Rossii. Pervye shagi [Forest Department in Russia. The first steps] [interactive]. 2013 [accessed on 2013-12-10]. <http:// www.krasrab.com/archive/2013/ 10/12/18/view_article $>$.

Shelgunov, N.V. Istoriya russkogo lesnogo zakonadatelstva [History of Russian Forest Legislation]. Sankt-Peterburg: Ministerstvo Gosudarstvennyh Imushchestv, 1857. 
Vilenskaya Arkheograficheskaya Komissiya. Reviziya pushch i perekhodov zverinych $v$ byvshem Velikom Knyazhestve Litovskom [Revision of dense forests and animal paths in the former Grand Duchy of Lithuania]. Vilna: V tipografii Gubernskogo Pravleniya, 1867.
Zhudra, P. Zagranichnye vpechatleniya russkogo lesnichego [Overseas Impressions of Russian Forester]. Lesnoi zhurnal. 1885, 9(2): 427-441.

\title{
VAKARIETIŠKI MIŠKININKYSTĖS MOKSLO MODELIAI RUSIJOS IMPERIJOJE LAIKOTARPIU NUO XVIII A. VIDURIO IKI XIX A. VIDURIO
}

\author{
Elena Lustina \\ Grodno valstybinis Jankos Kupalos universitetas, Baltarusijos Respublika \\ Mykolo Romerio universitetas, Lietuva
}

Santrauka. Straipsnyje apžvelgiama miškininkystès mokslo ir švietimo formavimasis ir plètra Rusijos imperijoje nuo XVIII a. vidurio iki XIX a. vidurio bei Vakaru Europos modeliu poveikis šiems procesams. Nüdienos ekologine situacija verčia atsižvelgti i gausybę miškų naudojimo ir tirtumo klausimų bei ị miškininkystès mokslą Rusijos Imperijoje ir Vakaru Europos šalyse.

Civilizuotų šalių istorijoje ryški tendencija: dèl mišku ištekliu naudojimo visuomenés, ekonomikos ir pramonés plètrai kyla mišku plotu nuskurdinimo problema. Todèl i mišku apsauga ir naudojima, i miškininkystès mokslus ir ju praktini pritaikyma bei patirties sklaida bütina žvelgti iš mokslo tyrimais pagrįstų pozicijų.

Aprašant miškininkystès mokslo ištakas ir kaitą Rusijos imperijoje skiriamos kelios raidos pakopos. Pirmajai pakopai būdingas tiesmukiškas Vakaru Europos modeliu kopijavimas. Vadovaudamasi miškininkystès praktika pažangesnèse Vakarǔ šalyse, Rusijos imperija taike kviestinių ekspertų metodiką. Straipsnio autorè aprašo iš Vokietijos kviestu ekspertu veikla, rezultatus, vizitu aplinkybes.

Antra pakopa siejama su domẻjimusi Vakaru Europos švietimu. Apžvelgiamos miškininkystès mokyklos keliose Vakaru Europos šalyse.

Trečioji pakopa - miškininkystès mokslo ir švietimo formavimasis Rusijos imperijoje. Atskleidžiamos problemos, susijusios su Vakaru Europos modeliu perkèlimu. Autore susitelkia ties formavimo ir plètros procesu, ties specifiniais Rusijos imperijos miškininkystès bruožais, atsiradusiais dèl Vakarų Europos šalių, ypatingai Vokietijos, miškininkystès modeliu poveikio.

Papaskutinè pakopa - miškininkystès švietimo ir mokslo įsiliejimas ị visuomeninị švietimą. Straipsnio pabaigoje pateikiamos tyrimo išvados.

Reikšminiai žodžiai: istorija, miškininkystès švietimas, Rusijos imperija, miškininkystè, miškosauga. 
Elena Lustina, Grodno valstybinis Jankos Kupalos universitetas, Mykolo Romerio universitetas, podoktorantūros studijų stažuotoja. Mokslinių tyrimų sritys: tautų istorija, aplinkosaugos ir aplinkosaugos strategijų istorija, struktūrinès miškų apsaugos sistemų organizacijos, visuomenès kultūros ir aplinkos santykis.

Elena Lustina, Yanka Kupala State University of Grodno, Doctoral student; Mykolas Romeris University, Exchange Doctoral student. Research interests: domestic history, history of environmental protection and environmental policies, structural organization of the forestry protection system, culture of society and environment interaction. 